\title{
Pomoc demokratyzacyjna polskich organizacji pozarządowych skierowana do Białorusi i Ukrainy: przesłanki oraz różne formy wsparcia ${ }^{1}$
}

Streszczenie: Wspieranie demokracji, czyli szczególny rodzaj pomocy zagranicznej mający na celu promowanie idei i postaw demokratycznych, było dotychczas domeną demokracji zachodnich. Dlatego badania w dziedzinie wspierania demokracji zazwyczaj koncentrowały się na programach prowadzonych przez międzynarodowe organizacje, bądź rządowe i pozarządowe organizacje, fundacje ze Stanów Zjednoczonych, jak również z Europy Zachodniej. Jednakże niedawno do grona darczyńców dołączyły również młode demokracje z Europy Środkowo-Wschodniej takie jak Polska, Czechy, Słowacja bądź Węgry, które same tak niedawno były odbiorcami tego typu pomocy. Biorąc jako studium przypadku działania Polski na Ukrainie i Białorusi niniejszy artykuł analizuje działania polskich organizacji pozarządowych na rzecz wspierania demokracji w krajach partnerskich w latach 1990-2015. Celem badań było zbadanie przyczyn zaangażowania się polskich organizacji pozarządowych we wspieranie demokracji, metod promowania idei i postaw demokratycznych oraz charakteru współpracy ze społecznością obywatelską z krajów partnerskich.

Słowa kluczowe: demokratyzacja, organizacje pozarządowe, Białoruś, Ukraina

\section{Wprowadzenie: Wspieranie demokracji przez młode demokracje}

W spieranie demokracji, czyli szczególny rodzaj pomocy zagranicznej mający na celu promowanie idei i postaw demokratycznych, było dotychczas domeną demokracji zachodnich (Alesina, Dollar, 2000; Burnell, 2000; Carothers, 1999, 2004; Diamond, 1992; Lancaster, 2007; Pinto-Duschinsky, 1997; Ottaway, Chung, 1999; Schraeder, Hook, Taylor, 1998; Youngs, 2006, 2008). Dlatego badania w dziedzinie wspierania

1 Badania finansowane w ramach projektu badawczego: „Ocena efektywności działań młodych krajów donatorów we wpieraniu demokracji w krajach demokratyzujących się", Narodowe Centrum Nauki, Program SONATA UMO-2013/09/D/ HS5/04381. 
demokracji zazwyczaj koncentrowały się na programach prowadzonych przez międzynarodowe organizacje, bądź rządowe i pozarządowe organizacje, fundacje ze Stanów Zjednoczonych, jak również z Europy Zachodniej. Jednakże niedawno do grona darczyńców dołączyły również młode demokracje z Europy Środkowo-Wschodniej takie jak Polska, Czechy, Słowacja bądź Węgry, które same tak niedawno były odbiorcami tego typu pomocy (Drążkiewicz-Grodzicka, 2013; Kugiel, 2011; Kucharczyk, Lowitt, 2008; Lightfoot, Szent-Ivantyi, 2014; Petrova, 2014; Pospieszna, 2014). W przeciwieństwie do wielostronnej współpracy rozwojowej, która świadczona jest za pośrednictwem wyspecjalizowanych organizacji i instytucji międzynarodowych i która przeznaczana jest do krajów wskazanych przez te organizacje, pomoc dwustronna kierowana jest głównie do krajów partnerskich. W krajach partnerskich, które są zbliżone geograficznie, jak i kulturowo oraz historycznie, nowi donatorzy upatrują możliwość realizacji polityki zagranicznej, jak i również szansę na stabilne i pokojowe sąsiedztwo. Dlatego kraje te uczyniły wspieranie demokracji jednym $\mathrm{z}$ istotnych filarów dwustronnej współpracy rozwojowej (Pospieszna, 2014; Pospieszna, 2010a; Pospieszna, 2010b).

Biorąc jako studium przypadku działania Polski na Ukrainie i Białorusi, niniejszy artykuł analizuje działania polskich organizacji pozarządowych na rzecz wspierania demokracji w krajach partnerskich w latach 1990-2015. Badania te oparte na materiałach, jak i wywiadach przeprowadzonych z przedstawicielami Polskiej Pomocy przy Ministerstwie Spraw Zagranicznych, licznymi przedstawicielami polskiego sektora pozarządowego ${ }^{2}$ oraz z National Endowment of Democracy (NED) z Waszyngtonu w Stanach Zjednoczonych. Celem badań było zbadanie przyczyn zaangażowania się polskich organizacji pozarządowych we wspieranie demokracji, metod promowania idei i postaw demokratycznych oraz charakteru współpracy ze społecznością obywatelską z krajów partnerskich.

${ }^{2}$ Ze względu na bezpieczeństwo realizatorów i beneficjentów projektów prowadzonych na terenie Białorusi artykuł nie podaje informacji o organizacjach ani o działaniach realizowanych w ramach projektów. Artykuł powołuje się na listę projektów zarówno tą upublicznioną wcześniej przez organizacje pozarządowe, jak na przykład lista projektów białoruskich sporządzona przez Fundację Batorego i Grupę Zagranica albo w ramach programu Przemiany w Regionie RITA, jak i na listę ze strony polskiej pomocy MSZ. Wiedza na temat współczesnych projektów białoruskich pochodzi z listy projektów która udostępniona została przez organizacje pozarządowe tylko na życzenie autora z zachowaniem dyskrecji. 
Istnieje kilka powodów wyboru Polski na studium przypadku. Program pomocy rozwojowej, tzw. Polska Pomoc, nadzorowany przez Departament Współpracy Rozwojowej i finansowany z funduszy rezerwy celowej budżetu państwa przeznaczonej na współpracę rozwojową dla Ministerstwa Spraw Zagranicznych, był jednym z pierwszych programów, który uczynił wspieranie demokracji i transformacji istotnym elementami współpracy rozwojowej. Programem zostały objęte Afryka Wschodnia, Azja, Bliski Wschód, ale przede wszystkim kraje Partnerstwa Wschodniego takie jak Białoruś, Gruzja, Mołdawia i Ukraina (MSZ, 2016), a polskie organizacje pozarządowe stały się kluczowym partnerem krajowym dzięki któremu możliwe jest dotarcie do społeczności obywatelskiej w tych krajach. Dla podkreślenia wagi znaczenia organizacji pozarządowych w realizacji projektów demokratyzacyjnych poza granicami Polski przemawia powstanie w 2012 r. Fundacji Solidarności Międzynarodowej (wcześniej funkcjonująca pod nazwami Polska Fundacja Transformacji Rynkowej „Wiedzieć Jak” oraz Polska Fundacja Międzynarodowej Współpracy na rzecz Rozwoju „Wiedzieć Jak”), która mocą przyjętej ustawy o współpracy rozwojowej, przejęła m.in. obsługę konkursów na realizację projektów przez polskie organizacje pozarządowe poza granicami Polski.

Ponadto, na uwagę zasługuje fakt, że wspieranie demokracji stało się najpopularniejszym kierunkiem zaangażowania polskich organizacji zanim powstał program pomocy rozwojowej pod filarami MSZ. W okresie transformacji wiele organizacji pozarządowych, które powstały i zalegalizowały swoją działalność zdobywało jednocześnie doświadczenie w przeprowadzaniu zmian społeczno-politycznych w Polsce. Niewątpliwe na powstanie i umocnienie się społeczności obywatelskiej w Polsce duży wpływ miała pomoc demokratyzacyjna pochodząca ze Stanów Zjednoczonych. Właśnie to wsparcie, jakie miało miejsce w Polsce prawdopodobnie stało się pewnym zobowiązaniem do wspierania w tym obszarze innych krajów oraz dzielenia się polskim doświadczeniem.

Ponadto, kolejnym argumentem przemawiającym za wyborem Polski do analizy jest to, że budowa demokracji, jak i przemiany gospodarcze w Polsce uznawane są za jedne z najbardziej udanych w regionie, dlatego Polska może być odpowiednim wzorem dla innych krajów dokonujących swoich przemian. Sukces transformacyjny czyni Polskę również bardziej wiarygodnym donatorem, a polskie organizacje które brały udział w tych zmianach automatycznie stały się jednym z rezerwuarów wiedzy i do- 
świadczenia który z pożytkiem może być wykorzystany poza granicami Polski, w szczególności w krajach bliskich nie tylko pod względem geograficznym.

Polska jest rozpoznawana ze swojego aktywnego i silnego społeczeństwa obywatelskiego, które przyczyniło się do upadku komunizmu (Ekiert, Kubik, 1999). Solidarność, która powstała na bazie strajków w Stoczni Gdańskiej, z czasem przekształcając się w związek zawodowy, była inspiracją dla społeczeństwa obywatelskiego w Polsce i poza jej granicami do tworzenia opozycji i domagania się swoich praw. Stając się z czasem nie tylko głosem robotników, ale i innych grup społecznych, Solidarność stworzyła nowy model pokojowej transformacji od sytemu autorytarnego do demokracji, w którym społeczeństwo obywatelskie odgrywa bardzo dużą rolę. Model ten spowodował że badacze uznali społeczeństwo obywatelskie za najlepsze podłoże rozwoju oraz konsolidacji współczesnej demokracji. Donatorzy, natomiast zaczęli przeznaczać w latach 90-tych wiele środków finansowych na budowanie i wzmacnianie organizacji pozarządowych w krajach postkomunistycznych. Bardzo szybko organizacje pozarządowe (non-governmental organizations, NGOs) stały się synonimem społeczeństwa obywatelskiego, które w warunkach demokracji miało wzmacniać kapitał ludzki, reprezentować społeczeństwo w relacjach z władzami publicznymi, jednocześnie wywierać wpływ i inspirować władze publiczne do podejmowania działań na rzecz społeczeństwa. Niemniej jednak wspieranie organizacji pozarządowych spotkało się z krytyką (Abramson, 1999; Adamosn, 2002; Hann, 2004; Helms, 2002; Henderson, 2003; Ishkanian, 2007; Mendelson, 2002; Wedel, 1998). Dostrzeżono, że mechanizm wsparcia przyczynia się do powstania organizacji, które czują się odpowiedzialne nie w stosunku do społeczeństwa, ale do donatorów, realizując projekty według odgórnych wytycznych, przyczyniając się jednocześnie do większej izolacji i wyobcowania organizacji.

Celem tego artykułu jest przedstawienie przyczyn oraz sposobu wspierania demokracji przez polskie organizacje pozarządowe oraz próba odpowiedzi na pytania: Czy projekty polskich organizacji pozarządowych wywierają wpływ na beneficjentów pomocy demokratycznej? Czy działania te przyczyniają się do szerzenia demokracji w regionie? Artykuł stawia hipotezę, że wypracowana strategia oparta na zasadzie partnerstwa oraz inne wypracowane zasady współpracy zwiększają prawdopodobieństwo przyczyniania się do większej efektywności pomocy demokratyzacyjnej w Ukrainie i Białorusi. Weryfi- 
kacja hipotezy została dokonana przez przedstawienie działań polskich organizacji w świetle krytyki wspierania demokracji przedstawionej w literaturze.

Artykuł ten pozwala lepiej zrozumieć czynniki zewnętrzne, które wpływają na procesy demokratyczne. Doświadczenia ostatnich 20-30 lat pokazują że kraje demokratyzują się regionalnie, czyli demokratyczne procesy w jednym z państw zwiększają prawdopodobieństwo na podobne procesy $\mathrm{w}$ innych państwach $\mathrm{w}$ regionie. Zjawisko to nazwane zostało efektem domina, dyfuzji (democracy diffusion), bądź lawiny (snowballing effect) (Bratton, van de Walle, 1997, s. 29; Huntington, 1991; Bunce, Wolchik, 2006; Brinks, Coppedge, 2006; Rogers, 1995, s. 10; Tarrow, 1998, 2005; Tarrow, della Porta, 2005; Gleditsch, Ward, 2006; O’Loughlin $\mathrm{i}$ in., 1998; Starr, 1991; Starr, Lindborg, 2003). Podobne zjawisko zostało zaobserwowane przez naukowców badających fenomen kolorowych rewolucji w postkomunistycznym regionie, które rozpoczęły się w 2000 roku (Bunce, Wolchik, 2006; Jacoby, 2006). Naukowcy wyjaśniają, iż proces rozpowszechnienia tego rodzaju rewolucji w regionie nastapił poprzez rozbudowaną sieć współpracy, która obejmowała nie tylko zagranicznych promotorów demokracji, ale również regionalne organizacje pozarządowe i lokalną społeczność obywatelską. Dlatego analizując wpływ projektów organizacji pozarządowych na młodych odbiorców, badanie to przyczynia się do lepszego zrozumienia procesu dyfuzji idei i postaw demokratycznych.

Analizując pomoc demokratyzacyjną i skuteczność projektów w dyfuzji norm, postaw i wartości, istotna jest odpowiedź na pytanie czy projekty organizacji są dostosowane do sytuacji politycznej kraju partnerskiego i czy są reakcją na konkretną potrzebę społeczeństwa obywatelskiego w tym kraju. Proces demokratyzacji zachodzi stopniowo, w okresie otwierania się systemu autorytarnego, a potem podczas liberalizacji, społeczeństwo ma inną rolę do spełniania (społeczeństwo jest zazwyczaj w opozycji do władz; bardziej prawdopodobne są gwałtowne ruchy protestacyjne) niż w późniejszej fazie demokratyzacji czy w dojrzałej demokracji (społeczeństwo wspiera, doradza i kontroluje; zazwyczaj mają miejsce bardziej pokojowe i konwencjonalne formy zaangażowania obywatelskiego) (Geremek, 1996, s. 250). Biorąc pod uwagę powyższe, rola jaką wspierana społeczność pełni w danym państwie w dużej mierze zależy od rodzaju reżimu i artykuł ten przedstawia próbę dostosowania działań mających na celu wspieranie tej społeczności. 


\section{Zaangażowanie się polskich organizacji pozarządowych we wspieranie demokracji}

Wspieranie demokracji (z ang. democracy assistance), czyli szczególny rodzaj pomocy zagranicznej mający na celu wspieranie idei i postaw demokratycznych jest jednym ze sposobów promowania demokracji (Diamond, 2016, s. 425; McFaul, 2005), który zazwyczaj uzupełnia działania dyplomatyczne. Wspieranie społeczeństwa obywatelskiego należy do jednych z najważniejszych filarów wspierania demokracji. Inne dziedziny pomocy demokratyzacyjnej dotyczą praw wyborczych, ochrony i promocji praw człowieka oraz wspierania niezależnych mediów (Carothers, 1999, 2004; Kumar, 2006). W Polsce wspieranie demokracji odbywa się w ramach wspomnianej pomocy rozwojowej. Jako członek Organizacji Współpracy Gospodarczej i Rozwoju (OECD), w której znajdują się najbardziej rozwinięte kraje na świecie, Polska dała wyraz że jest gospodarczo gotowa zostać darczyńcą pomocy dla innych krajów. Ponadto, wpływ Unii Europejskiej, która oczekuje od swoich członków zaangażowania nie tylko w wielostronną, ale i dwustronną pomoc rozwojową z zachowaniem odpowiednich proporcji oficjalnej pomocy rozwojowej (ODA) w stosunku do $\mathrm{PKB}^{3}$, spowodował że program pomocy rozwojowej przy MSZ musiał powstać. Niemniej jednak, mając swobodę w określeniu kierunków pomocy bilateralnej oraz wyboru obszarów wsparcia, wspieranie demokracji i dzielenie się doświadczeniem transformacji z krajami sąsiadującymi stało się istotnym obszarem współpracy rozwojowej. Dla Polski naturalnym wyborem stały się Białoruś i Ukraina, których znaczenie dla polskiej polityki zagranicznej nie daje się nie zauważyć w podejmowanych przez polski rząd oraz grupy społeczne działań na arenie międzynarodowej. Tutaj należy wspomnieć o wielu dyplomatycznych zabiegach polskiego rządu podczas Pomarańczowej Rewolucji jak i Euromajdanu, czy też takich inicjatywach jak Partnerstwo Wschodnie - specjalny instrument UE skierowany do bezpośrednich wschodnich sąsiadów Unii Europejskiej - którego powstanie wynikało między innymi ze starań Polski.

Ustawa o wspótpracy rozwojowej z 16 września 2011 r. art. 2 stanowi, że pomoc rozwojowa polega m.in. na ,promowaniu i wspieraniu rozwoju demokracji i społeczeństwa obywatelskiego, w tym rozwoju

3 Młode kraje UE miały osiągnąć poziom ODA/PKB w wysokości $0,17 \%$ do 2010 roku, a następnie 0,33\% do 2015 roku (Rada Unii Europejskiej, 2005). 
parlamentaryzmu, zasad dobrego rządzenia i przestrzegania praw człowieka”, podkreślając tym samym ścisłą zależność pomiędzy rozwojem gospodarczym a demokracją. Ponadto, Wieloletni program wspótpracy rozwojowej na lata 2016-2020 wskazuje że realizacja Milenijnych Celów Rozwoju (Millennium Development Goals, MDGs) oraz nowych zastępujących je od 2016 r. Celów Zrównoważonego Rozwoju (The Sustainable Development Goals, SDGs), które mają na celu wspieranie trwałego rozwoju społeczno-gospodarczego i podejmowanie działań zmierzających do redukcji ubóstwa jest możliwe dzięki wspieraniu demokracji i praw człowieka.

Niemniej jednak zaangażowanie Polski we wspieranie demokracji nie byłoby możliwe bez polskich organizacji pozarządowych, które tą aktywność rozpoczęły już na początku lat 90-tych. Polskie MSZ dostrzega $\mathrm{w}$ partnerstwie $\mathrm{z}$ organizacjami pozarządowymi szansę na uczynienie pomocy demokratyzacyjnej bardziej efektywnej ze względu na ich długoletnie doświadczenie we współpracy ze społecznością obywatelską na Białorusi i Ukrainie, a przez to i lepszą wiedzę na temat potrzeb kraju partnerskiego. Ponadto, dla polskiego rządu przekazywanie środków na obce konta organizacji pozarządowych nie jest możliwe również z prawnego punktu widzenia, tak więc jeżeli pomoc bilateralna ma trafić do społeczeństwa na Ukrainie i Białorusi, zazwyczaj odbywa się to przez finansowanie projektów organizacji pozarządowych.

Działalność organizacji pozarządowych we wspieraniu demokracji wykracza poza projekty finansowane z polskiej pomocy rozwojowej. Wiele organizacji pozarządowych nadal otrzymuje środki ze źródeł zagranicznych - od organizacji rządowych, takich jak National Endowement for Democracy (NED); prywatnych donorów, takich jak Open Society Institute w Nowym Jorku; Międzynarodowego Funduszu Wyszehradzkiego; Komisji Europejskiej; Fundacji Forda; Charles Stewart Mott Foundation; Szwedzkiej Agencji Międzynarodowej Współpracy Rozwojowej (Sida), Friedrich Ebert Stiftung, Robert Bosch Stiftung i Konrad Adenauer Stiftung. Wspierając projekty polskich organizacji pozarządowych skierowanych do Białorusi i Ukrainy, donatorzy wydają się doceniać wartość, jak i potencjał tej współpracy. Przedstawiciele NED, organizacji quasi-rządowej ze Stanów Zjednoczonych, która finansowała i nadal wspiera projekty polskich organizacji pozarządowych na Białorusi i Ukrainie, zapytani dlaczego organizacja zdecyduje się na współpracę z polskimi organizacjami pozarządowymi, podali kilka powodów. Po pierwsze, traktują polskie organizacje pozarządowe jako wiarygodnych 
partnerów, ponieważ współpracują z nimi od czasów transformacji kiedy to one były odbiorcami pomocy. Po drugie, polskie organizacje pozarządowe są bardziej aktywne we wspieraniu społeczeństwa obywatelskiego, co wynika z tego że posiadają pewne doświadczenie najpierw działając w podziemiu, a następnie jako legalne organizacje. Po trzecie, z powodu długotrwałej współpracy z partnerami białoruskimi i ukraińskimi, polskie organizacje pozarządowe nie tylko są w stanie lepiej dotrzeć do tych grup, ale również posiadają lepszą informację o sytuacji społeczeństwa obywatelskiego na Białorusi i Ukrainie, co przekłada się na lepiej dopasowane projekty. Według przedstawicieli NED, Polska ma dużo bardziej efektywne, niż w większości innych krajów, doświadczenie transformacji systemowej, a do jej sukcesów można zaliczyć: reformy w edukacji obywatelskiej, reformy samorządowe i powstanie lokalnej niezależnej prasy. Co więcej, Polska jest jedynym krajem z Europy Środkowo-Wschodniej, gdzie istnieje wiele NGO prowadzących działalność za granicą i które nie są tylko zlokalizowane w stolicy, ale także w innych regionach Polski, co natomiast przekłada się na ich doświadczenie związane $\mathrm{z}$ aktywizacją lokalnej społeczności.

$\mathrm{Na}$ istotny fakt zasługuje to, że polskie organizacje pozarządowe działające w obszarze pomocy demokratycznej często tworzone były przez byłych działaczy opozycji wywodzących się z, bądź działających w, Solidarności, którzy zdobywali zagraniczne środki na ten cel. Z wieloma donorami kontakty przetrwały od lat 90-tych, kiedy organizacje otrzymywały od nich pomoc na działania związane z przystosowywaniem polskiego społeczeństwa do zmieniających się warunków w wyniku transformacji systemowej oraz na ich większą aktywizację w życiu publicznym i społecznym ${ }^{4}$.

Niektóre fundacje takie jak Polsko-Amerykańska Fundacja Wolności, założona przez Polsko-Amerykański Fundusz Przedsiębiorczości powstały w 1990 roku w celu wspierania gospodarki rynkowej w Polsce, od samego początku za główny cel stawiała sobie rozwój społeczności lokalnych i wspieranie demokracji poprzez dzielenie się polskim doświadczenie $\mathrm{w}$ tym zakresie. Za flagowy projekt finansowany przez PAFW można uznać 9-miesięczny program stypendialny im. Lane’a Kirklanda,

${ }^{4}$ Fundacja Batorego jest jedną z organizacji pozarządowych, która miała na celu wsparcie rozwoju demokracji. Wartym uwagi jest fakt, że była to pierwsza zarejestrowana prywatna fundacja w Polsce po przemianach roku 1989. Jej głównym założycielem, a jednocześnie fundatorem był George Soros, Amerykański przedsiębiorca oraz działacz społeczny. 
realizowany od 2000 roku, który ukierunkowany jest na wspieranie demokracji oraz przemiany wolnorynkowe w państwach Europy Środkowej i Wschodniej. Ponadto, również od 2000 roku PAFW finansuje program Przemiany w Regionie - RITA, którego zadaniem jest dzielenie się doświadczeniem polskim w zakresie przemian demokratycznych, a także kształtowanie między innymi elit w społeczeństwie oraz nowych liderów (Janiszewska, Michałowski, 2010). Program ten również zajmuje się od 2004 roku realizacją studyjnych wizyt w Polsce (Study Tours to Poland - STP) dla profesjonalistów i młodych osób z Europy Wschodniej, mający na celu edukację o demokracji i zwiększanie świadomości obywatelskiej.

Wspomniane projekty wyróżnia to że są cykliczne i trwają nieprzerwanie od prawie już dwóch dekad, ale w porównaniu z różnorodnością i wielością innych projektów, które wdrażane były przez organizacje od lat 90-tych, są one tylko małym wycinkiem aktywności polskich organizacji pozarządowych. W celu realizacji tego badania, dokonana została również analiza projektów realizowanych przez organizacje pozarządowe należące do Grupy Zagranica. Grupa Zagranica jest federacją polskich organizacji pozarządowych zaangażowanych w międzynarodową współpracę rozwojową, wspieranie demokracji, pomoc humanitarną i edukację globalna. Niemniej jednak wspieranie demokracji to najpopularniejszy kierunek zaangażowania polskich organizacji zrzeszonych $\mathrm{w}$ federacji (Grupa Zagranica, 2012). Obserwacje i analiza została dokonana na podstawie dwudziestu organizacji z obszaru demokracja i prawa człowieka, wśród których można wymienić takie organizacje jak Fundacja Rozwoju Demokracji Lokalnej, która miała istotny wkład w powstanie polskiej reformy samorządowej i od początku swojej działalności prowadzi programy pomocowe m.in. na Ukrainie i Białorusi związane $\mathrm{z}$ tą tematyką, czy Fundacja Edukacja dla Demokracji, która najpierw w Polsce, a teraz poza granicami aktywizuje społeczeństwo i uczy odpowiedzialności obywatelskiej.

Wśród powodów zaangażowania się organizacji pozarządowych w projekty na Ukrainie i Białorusi najczęściej wymieniane były takie jak: 1) obowiązek pomocy wynikający z tego, że polskie organizacje pozarządowe same były odbiorcami pomocy w przeszłości; 2) impuls od Zachodnich donorów do prowadzenia działalności w innych krajach postkomunistycznych i dzielenia się swoim doświadczeniem; 3) geograficzna bliskość i większe prawdopodobieństwo, że pomoc zostanie dobrze wykorzystana; 4) popyt na polskie doświadczenie w procesach 
transformacyjnych, które postrzegane jest jako adekwatne do realiów społecznych i politycznych w Białorusi i na Ukrainie; 5) komplementarność w stosunku do działań dyplomatycznych w ramach realizowanej polityki zagranicznej w której Białoruś i Ukraina zawsze postrzegane były jako kraje priorytetowe ${ }^{5}$; 6 ) osobiste powody - wielu działaczy organizacji położonych w południowo-wschodniej Polsce, mając pochodzenie białoruskie bądź ukraińskie pragnie dla swoich krewnych tych samych swobód obywatelskich.

Ponadto, ze względu na historyczną przeszłość i wspólną kulturę z sąsiadami, polskim organizacjom pozarządowych łatwiej jest współpracować na Białorusi i Ukrainie. Polscy działacze społeczni czują się pewnie podróżując do innych krajów postkomunistycznych również z powodu braku barier językowych. Wielu aktywistów polskiego NGO ma białoruskie i ukraińskie korzenie i zna język swoich wschodnich partnerów, natomiast ci którzy nie znają ze względu na podobieństwo języków słowiańskich mogą komunikować się w swoim rodzimym języku.

Polskie organizacje pozarządowe wybrały specyficzny sposób realizacji programów demokratyzacyjnych, który oparty jest na zasadzie partnerstwa. W ramach partnerskich relacji, wiele projektów powstaje na skutek uzgodnień z partnerem ukraińskim bądź białoruskim, a następnie po uzyskaniu finansowania są wspólnie implementowane. Zasada partnerstwa wiąże się z tym że obowiązki związane z realizacją projektu są dzielone według kompetencji partnerów - na przykład polska organizacja pozarządowa daje swoje wsparcie merytoryczne, a organizacja ukraińska zajmuje się organizacją oraz dotarciem do bezpośrednich beneficjentów. Takie rozwiązanie jest też gwarantem efektywnego działania i daje możliwość osiagnięcia zamierzonego celu. Jednocześnie pokazuje, że polskie organizacje pozarządowe w przekazywaniu swojej wiedzy nie stosują gotowych rozwiązań.

Pojawia się jednak pytanie czy możemy zaobserwować pewne różnice w projektach kierowanych na Ukrainę i Białoruś, biorąc pod uwagę ich odmienne uwarunkowania polityczne. Następna sekcja odpowiada na to pytanie.

${ }^{5}$ Działacze organizacji pozarządowych wspominali, że wspieranie demokracji jest też szansą na stworzenie pozytywnych współczesnych stosunków pomiędzy Polakami a Ukraińcami i zatarcie negatywnych skojarzeń z wydarzeniami takimi jak Powstanie Chmielnickiego, Rzeź Wołyńska oraz Akcja „Wisła”. 


\section{Działania polskich organizacji pozarządowych skierowane do Białorusi i Ukrainy}

Wspieranie demokracji w warunkach systemu autorytarnego

Początki lat 90-tych otworzyły nowe możliwości współpracy i przepływu informacji oraz wiedzy pomiędzy polskimi a białoruskimi grupami społecznymi. Niemniej jednak w momencie przejęcia władzy na Białorusi przez Aleksandra Łukaszenkę forma współpracy oraz charakter działań w ramach pomocy demokratyzacyjnej musiały ulec zmianie. Po wprowadzeniu wielu instytucjonalnych i administracyjnych obostrzeń, funkcjonowanie niezależnych organizacji pozarządowych na Białorusi stało się niemożliwe. Białoruskie władze dostrzegając w organizacjach społecznych zagrożenie wymusiły na nich lojalność i zależność od władz, a te które nie chciały się podporządkować zostały zdelegalizowane. Ponadto, reżim Łukaszenki wszczął metody karania prodemokratycznych działaczy społecznych za współpracę z zagranicznymi partnerami, wprowadzając z czasem całkowity zakaz otrzymywania pomocy zagranicznej. Działania tych organizacji które brały udział w projektach finansowanych $\mathrm{z}$ tzw. niezarejestrowanych funduszy zewnętrznych uznawane były za nielegalny akt regulowany przez prawo karne (Chernov, 2008; Lenzi, 2002; Wilde, 2002; Sannikov, Kuley, 2006; Usau, 2007).

Biorąc pod uwagę zagrożenia dla Białorusinów wynikające z wprowadzonych przez reżim Łukaszenki zakazów, polskie organizacje pozarządowe musiały poszukać nowych rozwiązań związanych ze wspieraniem społeczeństwa obywatelskiego na Białorusi. Ponieważ nieliczne organizacje na Białorusi zdecydowały się kontynuować swoją działalność w podziemiu w formie zdelegalizowanych organizacji w opozycji do reżimu Łukaszenki, niektóre polskie organizacje powzięły ryzyko utrzymywania z nimi kontaktu oraz wspierania ich inicjatyw. Niemniej jednak dużo więcej polskich organizacji zdecydowało się współpracować bezpośrednio z beneficjentami: młodymi ludźmi, nauczycielami, rodzicami, pisarzami i tzw. liderami społecznymi.

Zmieniająca się forma projektów w ramach wspierania demokracji na Białorusi wynika ze świadomości organizacji pozarządowych, że powodzenie zależy od dokładnej znajomości kontekstu i sytuacji kraju partnera. Działania zmieniły się od tych jawnie podkreślających wspieranie demokracji, na takie które w mniej oczywisty sposób odwołują się do demokracji przez to nie doprowadzając do podejrzliwości czy bezpośredniej konfron- 
tacji z reżimem Łukaszenki. Na przykład, podczas wdrażania projektów polskie organizacje pozarządowe są ostrożne w używaniu takich słów jak „demokracja”, „,wolność”, ,prawa człowieka”, zastępując takimi jak ,partycypacja obywatelska”, ,aktywność lokalna”, lub ,świadomość społeczna", które nie są kojarzone działaniami demokratyzacyjnymi i nie prowokują władz. Podczas gdy na Białorusi kiedyś możliwe było zorganizowanie konferencji z białoruskim partnerem zatytułowanej „Od państwa autorytarnego do demokratycznego - charakter reform ustrojowych i gospodarczych w Republice Białoruś", która została przeprowadzona przez Centrum Edukacji Obywatelskiej Polska - Białoruś, dzisiaj takie projekty praktycznie nie istnieją (Fundacja Stefana Batorego/Grupa Zagranica, 2002).

Obecne projekty adresowane do Białorusi podkreślają rozwój kapitału społecznego i ludzkiego, rozwój lokalny i zwiększanie uczestnictwa w życiu społecznym. Celem projektów jest aktywizacja białoruskich społeczności lokalnych w celu poprawy ich funkcjonowania - projekty zachęcają miejscową ludność do podejmowania działań mających na celu rozwiązanie problemów społecznych, nawet jeśli odnoszą się one do takich małych działań jak sprzątanie osiedli, tworzenie lokalnej rady osiedlowej lub poprawy lokalu mieszkalnego. Projekty te mają na celu uświadomienie społeczności lokalnej, że mogą same zmieniać coś w swoim otoczeniu i podejmować inicjatywy nie czekając na gotowe rozwiązania od władz centralnych. Działaniom tym przyświeca myśl, że im społeczeństwo aktywniejsze i uświadomione tym bardziej chętne do przenoszenia tej aktywności na wyższe szczeble partycypacji obywatelskiej.

Nawet jeśli projekty z pozoru mogą wydawać się za niemające wiele wspólnego z demokracją albo budowaniem społeczeństwa obywatelskiego, z punktu widzenia teorii demokratyzacji ważne w tych działaniach jest to że białoruska społeczność utrzymuje kontakty z polską społecznością, dzięki czemu następuje proces socjalizacji, który, jak badania pokazały, jest bardzo istotnym czynnikiem przyczyniającym się do dyfuzji norm i postaw demokratycznych (Checkel, 2005; Schimmelfennig, Engert, Knobel, 2006). Polskie organizacje pozarządowe wydają się rozumieć tą prawidłowość - mimo że, działania w sferach edukacji, kultury, turystyki i inicjatyw lokalnych nie odnoszą się do demokratyzacji w bezpośredni sposób, projekty te dają okazję do dyskusji, interakcji z białoruskimi partnerami, przyczyniając się do wzrostu ich świadomości, wiedzy i pewności siebie, a w pośredni sposób do budowania mocniejszego społeczeństwa obywatelskiego.

Dostrzegając, że rząd w Mińsku nie promuje białoruskiej tożsamości narodowej, zwłaszcza języka białoruskiego, i utrudnia działalność 
w dziedzinie kultury i nauk humanistycznych tym, którzy tą tożsamość pielęgnuja, polskie organizacje pozarządowe stworzyły dogodne warunki umożliwiające społeczności białoruskiej na rozwijanie swojej kultury. Dla wielu pisarzy możliwość wydania w Polsce ich dzieł w postaci esejów historycznych w języku białoruskim, monografii historycznych, listów białoruskich emigrantów oraz słownika języka białoruskiego, jest jedyną szansą, aby te dzieła mogły być opublikowane. Ponadto, artyści, muzycy, malarze oraz fotografowie, którzy przyczyniają się do budowy białoruskiej tożsamości narodowej poprzez propagowanie kultury białoruskiej mogą wziąć udział w licznych wydarzeniach artystycznych, takich jak na przykład coroczny Festiwal Niezależnej Kultury Białoruskiej we Wrocławiu. Przedstawiciele polskich organizacji pozarządowych aktywnie promujący kulturę białoruską uzasadniają ich zaangażowanie tym, że taka działalność może dać odczucie solidarności społecznej wynikające z silnej białoruskiej tożsamości kulturowej. Takie poczucie przynależności, jedności i solidarności natomiast z czasem może wzmacniać kapitał ludzki i mieć istotny wkład w walkę o demokrację tego kraju.

Ponieważ dostęp do niezależnych informacji o wydarzeniach krajowych i zagranicznych ma kluczowe znaczenie dla społeczeństwa białoruskiego, polskie organizacje pozarządowe angażują się także w tworzeniu nowych mediów, które w mniejszym stopniu kontrolowane są przez reżim Prezydenta Łukaszenki. W ramach jednego z projektów było stworzenie Radio Racja z siedzibą w Białymstoku. Radio adresowane jest do mieszkańców Białorusi oraz do mniejszości białoruskiej mieszkającej w Polsce. Radio zapewnia obiektywne wiadomości i analizy z Białorusi i zagranicy. Radiostacja posiada również własny internetowy serwis informacyjny po białorusku z aktualnościami o Białorusi. Dostrzegając rosnące znaczenie mediów elektronicznych jako źródeł informacji i komunikacji, polskie organizacje pozarządowe stworzyły wiele portali internetowych, takich jak Kamunikat czy Belarus Live, które zapewniają dostęp do informacji i artykułów napisanych w języku białoruskim o białoruskiej historii i literaturze, oraz o obecnych wydarzeniach społecznych i politycznych na Białorusi (MSZ, 2008).

Wspieranie demokracji w kraju demokratyzującym się

W przypadku Ukrainy od początku lat 90-tych współpraca polskich organizacji pozarządowych z szeroko pojętym społeczeństwem obywa- 
telskim (organizacjami pozarządowymi, wolontariuszami, stowarzyszeniami branżowymi, związkami zawodowymi, mediami, instytutami badawczymi, niezależnymi badaczami i innymi ekspertami) odbywa się bez większych zakłóceń, przyczyniając się do rozwoju i pogłębienia współpracy. Celem projektów jest wzmacnianie potencjału organizacji pozarządowych; edukacja nieformalna o demokracji, transformacji systemowej i Unii Europejskiej; zwiększanie aktywnego udziału obywateli, w szczególności młodych ludzi, w życiu społecznym; wspieranie wolnych mediów; zwiększania świadomości społecznej z zakresu przysługujących im praw, ochrony i opieki ze strony państwa; integracja społeczna i wzmocnienie zaufania.

Taka współpraca jest możliwa, ponieważ Ukraina, w przeciwieństwie do Białorusi, jest krajem, w którym zachodzą stopniowe procesy demokratyczne ${ }^{6}$. Społeczeństwo nawet za czasów Prezydentów Krawczuka i Kuczmy cieszyło się dużo większymi swobodami niż obecne społeczeństwo białoruskie, dlatego polskie organizacje pozarządowe zaangażowane w proces transformacji w Polsce jednocześnie mogło zacząć współpracę z nowopowstającymi, niezależnymi i apolitycznymi grupami społecznymi na Ukrainie. Taka długoletnia współpraca przyczyniła się między innymi do wzmocnienia społeczeństwa które zaangażowane było w przygotowanie i przeprowadzenie Pomarańczowej Rewolucji w 2004 roku? . Ukraińskie władze wybrały kierunek prozachodni i proeuropejski, ale który nie jest taki oczywisty dla całego społeczeństwa, co dało się zauważyć podczas i po Euromajdanie. Dodatkowo secesja i przyłączenie Krymu do Rosji oraz konflikt we wschodnio-południowej Ukrainie wywołany przez separatystów prorosyjskich, które są negatywnymi konsekwencjami Euromajdanu spowodowały, że Ukraina musi zmierzyć się z wyzwaniami, które stawiają konsolidację demokracji pod znakiem zapytania.

Czynniki geopolityczne, historyczne i ekonomiczne odgrywają rolę w polaryzacji ukraińskiego społeczeństwa. Po uzyskaniu niepodległości stało się oczywistym, że Ukraina składa się z dwóch wyraźnie różniących się części: zachodniej i wschodniej. Oprócz różnic językowych (w zachodniej części mieszkańcy posługują się ukraińskim, we wschodniej

6 Według indeksu Polity IV w skali od -10 (system autorytarny) do 10 (demokracja), Ukraina otrzymała 6 punktów w 2015 roku. Według Freedom House uznawana jest za częściowo wolną (partly free), a wolności obywatelskie, jak i polityczne oceniane zostały na $3 \mathrm{w}$ skali od 1 do 7.

7 Więcej na temat roli polskich organizacji pozarządowych przed i podczas Pomarańczowej Rewolucji w Pospieszna (2014). 
natomiast przede wszystkim rosyjskim), istnieje dużo istotnych różnic związanych z tożsamością narodową oraz upodobaniami geopolitycznymi (D'Anieri, 2007a; Barrington, 2002; Barrington, Herron, 2004; Hesli i in., 1998; Kuzio, 2006; Osipian, Osipian, 2006; Shulman, 2005; Wilson, 2006). Wpływ tych różnic widoczny był podczas wyborów, a w szczególności podczas wyborów prezydenckich w 2004 roku, a co więcej, polaryzacja społeczeństwa w odniesieniu do przemian demokratycznych została użyta przez ukraińskich przywódców również jako narzędzie w walce o władzę polityczna, przyczyniając się do pogłębienia różnic pomiędzy wschodnimi i zachodnimi obwodami (AFP, 2007; Kuzio, 2007).

Badacze podkreślają, że polaryzacja społeczeństwa $\mathrm{w}$ odniesieniu do przemian demokratycznych może mieć negatywny wpływ na rozwój silnego społeczeństwa obywatelskiego i na procesy demokratyzacyjne. Badacze zwracają uwagę na rolę kultury politycznej, czyli ogółu postaw, wartości i wzorów zachowań dotyczących rządzących i stosunków władza-obywatel na rozwój demokracji (Almond, Verba, 1963, s. 369; Inglehart, 1988; Putnam i in., 1983). Nieporozumienie co do najistotniejszych kwestii takich jak władza powinna być sprawowana powoduje, że kultura demokratyczna nie będzie mogła się wykształcić. Polskie organizacje pozarządowe wydają się rozumieć te zależności, ponieważ już od początku lat 90-tych powstawało wiele projektów, które miały jednoczyć społeczeństwo ukraińskie, w którym silnie zaznacza się zróżnicowanie historyczne, językowe, kulturowe i polityczne.

Wątki integracyjne pomiędzy wschodnią a zachodnią Ukrainą często były i są podkreślane w działaniach polskich organizacji takich jak Fundacja Stefana Batorego, Fundacja Rozwoju Demokracji Lokalnej (FRDL) czy Fundacja Edukacja dla Demokracji. Projekty te często uwzględniają nie tylko partnera z zachodniej części Ukrainy, ale także ze wschodniej. Naturalną rzeczą jest to, że wiele polskich organizacji ma trwalsze i długoletnie kontakty z organizacjami z zachodniej bądź centralnej Ukrainy, co wynika nie tylko z bliskości geograficznej, ale również z faktu że właśnie w tym obszarze w dużych miastach powstawały pierwsze organizacje pozarządowe. Potrzeba lepszej integracji, wymiany informacji o problemach charakterystycznych dla danego regionu, spowodowały że polskie organizacje zainicjowały, poprzez partnerskie organizacje z zachodniej części Ukrainy, współpracę z organizacjami ze wschodnich obwodów. Taka trójstronna, niezakłócona i systematyczna współpraca w ramach projektów stanowić może nie tylko czynnik integrujący społeczeństwo ukraińskie, ale może przyczynić się do lepszego rozwoju organizacji we wschodniej czę- 
ści, które są małe, wyizolowane i podatne na niepożądane wpływy różnych grup nacisku, zarówno politycznych, jak i biznesowych ${ }^{8}$.

W przypadku Ukrainy projekty nie tylko mają na celu wzmocnienie społeczeństwa obywatelskiego, ale także wsparcie programów działania oraz zmian systemowych na Ukrainie najpierw po Pomarańczowej Rewolucji, a obecnie po Euromajdanie. Projekty polskich organizacji pozarządowych w partnerstwie z ukraińskimi koncentrują się na zwiększeniu możliwości państwa i jego instytucji oraz poprawy legitymizacji i przejrzystości administracyjnej sektora publicznego. W szczególności organizacje pozarządowe kładą szczególny nacisk na podniesienie świadomości społeczeństwa na temat wagi trójpodziału władzy w Ukrainie, ale także przekonują o celowości decentralizacji władzy politycznej jako głównego warunku konsolidacji demokratycznej. W osiagnięciu tego celu upatrują wzmocnienie kompetencji i aktywizację lokalnych elit zaangażowanych w różnego rodzaju reformy, w szczególności w reformy samorządowe.

Projekty te często uwzględniają nie tylko przedstawicieli ukraińskich organizacji pozarządowych, ale również władze lokalne. Takie wspólne projekty mają na celu wzmocnienie roli ukraińskich organizacji pozarządowych i postrzegania ich przez społeczeństwo jako istotnego partnera dla administracji lokalnej kształtującego sferę publiczną. Ponadto, dzięki takim projektom władze lokalne dostrzegają znaczenie organizacji pozarządowych jako istotnego aktora lokalnego, który nie tylko kształtuje postawy obywatelskie i społeczne, ale także może mieć istotny wkład w rozwój inicjatyw publicznych. Nadal organizacje, które wykazują zainteresowanie sprawami publicznymi i wolę brania udziału w procesach decyzyjnych, traktowane są z dużą nieufnością przez władze lokalne. Dlatego wspólne projekty mają na celu podniesienie poziomu dialogu pomiędzy władzami a lokalną społecznością reprezentowaną przez organizacje społeczne, co z kolei przyczyni się do zwiększenia udziału tych ostatnich w planowaniu, realizacji oraz kontroli działań lokalnych.

${ }^{8}$ Przykładem projektu, w którym znajdują się dwaj ukraińscy partnerzy - jeden z Zachodu i drugi ze Wschodu to projekt zainicjowany przez FRDL 2007/2008 w Krakowie i wdrażany z ukraińską organizacją pozarządową z Iwano-Frankowska a innym NGO ze wschodniego obwodu, Doniecka. Projekt zatytułowany „Jestem obywatelem: kształtowanie postaw obywatelskich wśród młodzieży na Ukrainie" adresowany był do młodych ludzi w Doniecku o dotyczył aktywizacji i zwiększania świadomości na temat problemów społecznych i lokalnych. Na podstawie listy projektów otrzymanej od organizacji. 
Projekty, które łączą przedstawicieli ukraińskich i polskich działaczy organizacji, ukraińskich partii politycznych, władz lokalnych, regionalnych czy państwowych stwarzają również szansę do dyskusji, wymiany poglądów co sprzyja możliwości wypracowania lepszych rozwiązań. Korzyści płynące z takiej współpracy dla jednostek samorządu terytorialnego to przede wszystkim: zwiększenie możliwości efektywnego świadczenia usług publicznych, bardziej gospodarne wykorzystanie posiadanych zasobów oraz lepsze dopasowanie do potrzeb i wymagań lokalnej społeczności. Ponadto, taka współpraca sprzyja również wizerunkowi władz lokalnych, szczególnie we wschodniej Ukrainie, gdzie społeczeństwo nadal jest zdystansowane i nieufne w stosunku do rządzących. Uczestnictwo lokalnych urzędników w projektach organizacji pozarządowych przyczynia się do postrzegania ich przez lokalną społeczność jako otwartych, dostępnych i bardziej ,ludzkich”.

Wsparcie w celu wzmocnienia niezależnych mediów było i nadal jest również istotnym obszarem działalności polskich organizacji pozarządowych na Ukrainie. Niemniej jednak wyłania się jedna z podstawowych różnic - biorąc pod uwagę silną propagandę i indoktrynację w tradycyjnych mediach (państwowych) i ich całkowite podporządkowanie się reżimowi Łukaszenki, wspieranie niezależnych stacji telewizyjnych, prasy oraz dziennikarzy jest bardzo trudne, a praktycznie nawet niewykonalne. Natomiast w przypadku Ukrainy, działalność w obszarze wspierania niezależnych mediów i dziennikarzy jest możliwe i miało miejsce już przed Pomarańczową Rewolucją. Projekty wspierania wolnych mediów i wolności słowa nadal skupiają się na szkoleniu dziennikarzy, wierząc że niezależne media zatrudniające kompetentnych dziennikarzy, to jeden z filarów demokratycznego państwa. Treningi mają na celu zwiększenie zainteresowania dziennikarzy tematyką lokalną charakterystyczną dla danego regionu i rozwinięcie umiejętności dziennikarzy do podejmowania dyskusji na temat lokalnych reform. Ponadto, w ramach projektów wspierających media, polskie organizacje dziennikarskie przekazują swoje doświadczenie w walce z korupcją, sprawowaniem kontroli nad instytucjami publicznymi i promocji swoich działań w społeczeństwie.

Biorąc pod uwagę obecną sytuację na Ukrainie projekty również dostosowują się do aktualnych potrzeb społeczeństwa. W ostatnich czasach można zaobserwować wzrost projektów mających na celu wspieranie dziennikarstwa śledczego w ukraińskich mediach regionalnych i lokalnych. Dziennikarze zdobywają wiedzę i uczą się jak stać na straży reform samorządowych i decentralizacji władzy oraz ograniczać ryzyko ich 
niepowodzenia bądź pokazywać obszary, w których zachodzą nadużycia. Ponadto, w czasach wojen informacyjnych i konfliktów, dziennikarze szczególnie z terenów Ukrainy objętych inwazją rosyjską, uczą się swojej nowej roli.

Wspieranie mediów oparte jest na podstawowym założeniu, że wolne media i wolność słowa sąjednym z najważniejszych elementów demokracji. Organizacje pozarządowe dostrzegają we współpracy z dziennikarzami szansę w zwiększaniu transparentności działań władz, przyczyniając się do budowy społecznego zaufania, tak jak to miało miejsce w Polsce w trakcie transformacji, dlatego uznają za istotne przekazanie tego doświadczenie innym państwom z regionu.

Nowe wyzwania i możliwości, które pojawiły się na Ukrainie po Pomarańczowej Rewolucji dały nowe pomysły na współpracę polskich organizacji pozarządowych i ukraińskiego społeczeństwa obywatelskiego. Wprawdzie Ukraina podpisała z Unią Europejską układ o partnerstwie i współpracy w latach 90-tych, dopiero relacje porewolucyjne spowodowały obranie bardziej pro-europejskiego kursu w polityce nowego rządu który złożył oświadczenie o ubieganie się o członkostwo w UE. Popularne były projekty, które miały na celu podniesienie świadomości i wiedzy na temat Unii Europejskiej, a przez to zwiększające poparcie społeczeństwa i klasy rządzącej dla integracji europejskiej. Projekty miały pomóc władzom w stworzeniu odpowiednich struktur umożliwiających dialog polityczny z Brukselą, ułatwienie Ukrainie dostosowania się do unijnych norm i wartości, a obywatelom uświadomienie korzyści płynących z większej współpracy z UE.

Mając duże doświadczenie we wprowadzaniu polskiego społeczeństwa do struktur unijnych, polskie organizacje pozarządowe upatrują w bliższej integracji z Unią możliwość umocnienia i konsolidacji procesów demokratyzacyjnych. Niemniej jednak projekty o tematyce unijnej wynikały z samego zainteresowania i chęci ukraińskiego społeczeństwa do zbliżenia się do Unii Europejskiej. Powstało wiele projektów w których polskie organizacje dzieliły się swoim doświadczeniem, takim jak tworzenie w szkołach tzw. Szkolnych Klubów Europejskich, w którym nauczyciele oraz uczniowie zdobywali i wzmacniali swoją wiedzę o historii, kulturze i instytucjach Unii Europejskiej. Wiele programów dotyczących integracji z UE kierowanych było do młodych ludzi, a także pracowników służby cywilnej na szczeblu centralnym i lokalnym, dziennikarzy i think tanków, którzy poprzez spotkania warsztatowe z zakresu edukacji europejskiej nie tylko zdobywali wiedzę na temat integracji europejskiej, 
ale również przygotowywali się do sprostania wymaganiom związanym z perspektywą ściślejszej współpracy, a nawet przyszłego członkostwa Ukrainy w UE. Demonstracje 21 listopada 2013 roku przeciwko odroczeniu przez prezydenta Wiktora Janukowycza podpisania umowy stowarzyszeniowej z UE, które przerodziły się w rewolucję na Placu Niepodległości, doprowadzając do przewrotu, pokazały że społeczeństwo ukraińskie jest świadome korzyści płynących z integracji z Unią Europejską.

Obecne wyzwania będące pokłosiem rewolucji Euromajdanu takie jak kryzys krymski oraz prorosyjski separatyzm we wschodniej i południowej części Ukrainy, w wyniku którego zagrożona jest suwerenności Ukrainy, mają swoje odzwierciedlenie w działalności polskich organizacji pozarządowych na Ukrainie. Popularne stały się projekty kierowane do społeczności lokalnych wschodnich i południowych regionów Ukrainy w celu wsparcia prodemokratycznych środowisk ukraińskich. Działania mają nie tylko charakter informacyjny, ale mają również służyć wypracowaniu lokalnych inicjatyw obywatelskich, wzmacnianie dialogu pomiędzy społeczeństwem a władzami w celu opracowania konkretnych strategii działań środowisk prodemokratycznych oraz przygotowania planu działań niezbędnych do przeprowadzenia reform. Taki trend można zauważyć nie tylko wśród projektów finansowanych przez Fundację Solidarności Międzynarodowej z funduszy pomocy rozwojowej w ramach obszaru wspierania demokracji, ale także wśród projektów finansowanych przez Polsko-Amerykańską Fundację Wolności.

Tabela $1 \mathrm{w}$ sposób syntetyczny ujmuje rodzaje projektów organizacji pozarządowych skierowanych do Białorusi i Ukrainy. Należy również podkreślić, że istnieją projekty wsparcia demokracji, które nie uwzględniają specyfiki kraju partnerskiego. Do takich projektów należą wizyty studyjne, staże, stypendia i inne projekty edukacyjne, które mają miejsce w Polsce i są skierowane do wielu uczestników krajów Partnerstwa Wschodniego. Oczywiście organizatorzy, biorąc pod uwagę specyfikę kraju w momencie rekrutacji i dotarcia do potencjalnych uczestników, ale treści przekazywane i wiedza merytoryczna jest uniwersalna dla wszystkich odbiorców.

Podsumowując, z analizy zebranej dokumentacji, pogłębionej o przeprowadzone wywiady i lata współpracy z organizacjami pozarządowymi, wyłania się konkluzja, że polskie organizacje pozarządowe aktywnie dzielą się swoim doświadczeniem transformacji systemowej, a współpraca uwzględnia tło historyczne, polityczne, społeczne i kulturowe krajów, które są beneficjentami wsparcia. Dla wsparcia hipotezy, że projekty 
polskich organizacji pozarządowych są efektywne i że mogą przyczynić się do szerzenia demokracji w regionie, przedstawiona zostanie krytyka wypracowanych technik przez zachodnich donatorów.

Tabela 1

Wspieranie demokracji przez polskie organizacje pozarządowe z uwzględnieniem sytuacji politycznej kraju odbiorcy

\begin{tabular}{|c|c|}
\hline Białoruś & Ukraina \\
\hline $\begin{array}{l}\text { Współpraca z zdelegalizowanymi organi- } \\
\text { zacjami prodemokratycznymi i/lub bezpo- } \\
\text { średnio z młodymi ludźmi, nauczycielami, } \\
\text { rodzicami oraz lokalnymi liderami. }\end{array}$ & $\begin{array}{l}\text { Współpraca z organizacjami pozarządo- } \\
\text { wymi, władzami lokalnymi, mediami, } \\
\text { niezależnymi dziennikarzami, instytutami } \\
\text { badawczymi, think tankami. }\end{array}$ \\
\hline $\begin{array}{l}\text { Projekty mające pośredni charakter demo- } \\
\text { kratyzujący - działania w sferach edukacji, } \\
\text { kultury, turystyki i inicjatyw lokalnych. }\end{array}$ & $\begin{array}{l}\text { Projekty wspierające zmiany systemowe, } \\
\text { zwiększenie możliwości państwa i jego in- } \\
\text { stytucji. }\end{array}$ \\
\hline Rozwój kapitału społecznego i ludzkiego. & $\begin{array}{l}\text { Zwiększanie legitymizacji i przejrzystości } \\
\text { administracyjnej sektora publicznego po- } \\
\text { przez projekty pomiędzy społeczeństwem } \\
\text { a władzami. }\end{array}$ \\
\hline $\begin{array}{l}\text { Działania mające na celu zwiększenie po- } \\
\text { czucia przynależności i solidarności spo- } \\
\text { łecznej. }\end{array}$ & $\begin{array}{l}\text { Działania mające na celu jednoczenie spo- } \\
\text { łeczeństwa ukraińskiego, w którym silnie } \\
\text { zaznacza się zróżnicowanie historyczne, } \\
\text { językowe, kulturowe i polityczne (projekty } \\
\text { Zachód-Wschód). }\end{array}$ \\
\hline $\begin{array}{l}\text { Rozwój lokalny i zwiększanie uczestnictwa } \\
\text { w życiu społecznym. }\end{array}$ & $\begin{array}{l}\text { Podniesienie świadomości społeczeństwa } \\
\text { na temat celowości decentralizacji władzy } \\
\text { politycznej. }\end{array}$ \\
\hline $\begin{array}{l}\text { Promowanie białoruskiej tożsamości naro- } \\
\text { dowej. }\end{array}$ & $\begin{array}{l}\text { Podniesienie świadomości i wiedzy na te- } \\
\text { mat Unii Europejskiej, a przez to zwiększa- } \\
\text { nie poparcia społeczeństwa i klasy rządzą- } \\
\text { cej dla integracji europejskiej. }\end{array}$ \\
\hline $\begin{array}{l}\text { Tworzenie nowych mediów elektronicz- } \\
\text { nych jako źródeł informacji i komunikacji. }\end{array}$ & $\begin{array}{l}\text { Wzmacnianie niezależnych stacji telewi- } \\
\text { zyjnych, prasy oraz dziennikarzy. }\end{array}$ \\
\hline
\end{tabular}

Źródło: Opracowanie własne na podstawie analizy projektów polskich organizacji pozarządowych.

\section{Próba ewaluacji wpływu pomocy demokratyzacyjnej polskich organizacji pozarządowych}

Jedną z najczęstszych krytyk, która pojawia się w badaniach nad wspieraniem demokracji przez świat zachodni w innych państwach postkomunistycznych jest to, że darczyńcy niewiele zrobili w celu dostoso- 
wania projektów do warunków krajowych i lokalnych kraju odbiorcy. Badacze twierdzą, że zachodnie organizacje działały mając niewielką wiedzę na temat kraju partnerskiego, narzucały zachodnie praktyki i rozwiązania, zaniedbując jego uwarunkowania historyczne, kulturowe i społeczne. Promując społeczeństwo obywatelskie przeoczyły fakt, że społeczeństwo obywatelskie jest agregatem lokalnych potrzeb i interesów oraz lokalnej kultury i polityki. Co więcej, badacze zwracają uwagę na to że świadczące pomoc zachodnie organizacje niewiele wiedząc o przemianach demokratycznych starały się stosować te same wzorce wsparcia w każdym kraju i wymuszały na krajach partnerskich korzystających z pomocy do pokonania tej samej drogi transformacji, niezależnie od panujących warunków społecznych i politycznych. Programy opracowane w zachodnich stolicach nie uwzględniały specyfiki każdego kraju z osobna, ani co jest pożądane i możliwe w tych krajach. Ponieważ demokratyzacja jest odmiennym doświadczeniem w różnych krajach i regionach, pomoc demokratyzacyjna powinna być dostosowana do kraju odbiorcy (Aksartova, 2005; Carothers, 1999, 2004, 1999; Grugel, 1999; Hadenius, Uggla, 1998; Henderson, 2002, s. 155; Henderson, 2000, 2003; McMahon, 2002, 2004; Narozhna, 2004; Mendelson, Glenn, 2002, s. 4; Ottaway, 2003; Ottaway, Chung, 1999; Quigley, 2000, s. 192; Siegel, Yancey, 1992, s. 57-58; Sundstrom, 2006).

Współpraca partnerska polskich organizacji pozarządowych z grupami społecznymi na Ukrainie i Białorusi kontrastuje z modelem stosowanym często w Polsce na początku lat 90-tych, znanym jako „Brygady Marriotta” („The Marriott Brigade”) (Wedel, 1998; Kieżun, 2011). W przeciwieństwie do zachodnich doradców przybywających do Polski na zlecenie międzynarodowych instytucji finansowych i dawców pomocy rozwojowej w celu prowadzenia szkoleń w hotelu Marriott na temat zmian demokratycznych i budowy gospodarki wolnorynkowej, nie rozumiejąc i nie znając polskich realiów, współpraca partnerska ma swoją przewagę, ponieważ poprzez angażowanie społeczności obywatelskiej istnieją szanse, że projekty będą lepiej dopasowane, uwzględniając kontekst krajowy w kraju odbiorcy. Dodatkowo, będąc częścią opozycji i mając doświadczenie związane z działalnością w podziemiu podczas reżimu autorytarnego działacze polskich organizacji pozarządowych uważają, że są przygotowani do pracy na Białorusi oraz do radzenia sobie z przeszkodami ze strony białoruskiego reżimu i wydają się nie zrażać technikami represji i prowokacji służb specjalnych. Tak więc, ze względu na lepszą znajomość sąsiadujących partnerów i rozumienia wewnętrznych warun- 
ków, norm i sytuacji politycznej, projekty polskich organizacji pozarządowych dotyczące Białorusi i Ukrainy mają szansę być bardziej skuteczne niż inne strategie w zakresie pomocy demokracji.

W wyniku partnerstwa tworzona jest również tzw. „własność lokalna" (local ownership) projektów pomocowych (Carothers, 1999; Quigley, 2000), czyli wiedza i narzędzia udostępniane przez donorów pomocy powinny znajdować się w rękach społeczności lokalnej, której te projekty dotyczą nie tylko podczas wdrażania projektu, ale i po realizacji projektu.

Gdy zachodni donatorzy zapewniali, że przekazują pomoc na wsparcie społeczeństwa obywatelskiego, zazwyczaj odnosili się to do wsparcia dla organizacji pozarządowych (Carothers, 1999, s. 210; Raik, 2006, s. 175; Hadenius, Uggla, 1996; Mitilin, 1998; USAID Mission to Poland Europe and Eurasia, 1999). Niewatpliwie organizacje pozarządowe są ważnym elementem społeczeństwa obywatelskiego, ponieważ pomagają obywatelom w rozwiązywaniu problemów społecznych, lobbują rząd w imieniu obywateli, promują świadomość i wywierają nacisk na przejrzystość w rządzie i biznesie. Niemniej jednak nie mogą i nie powinny być celem samym w sobie, a w krajach w których stosowane są represje w stosunku do niezależnych organizacji, w wyniku czego przestają one istnieć, stawianie znaku równości pomiędzy wspieraniem społeczności obywatelskiej a organizacjami pozarządowymi jest nieadekwatne (Henderson, 2000, 2003; Carothers, 2004; Rose-Ackerman, 2007). Jak zostało to przedstawione $\mathrm{w}$ poprzedniej sekcji, polskie organizacje pozarządowe, zwłaszcza w przypadku współczesnej Białorusi, gdzie wolność organizacji niezależnych jest ograniczona, starają się dotrzeć do różnych grup społecznych. Również w przypadku Ukrainy, większość przedstawicieli polskich organizacji pozarządowych jest przekonana, że ich współpraca ze studentami, nauczycielami i innymi organizacjami społecznymi w pewnym stopniu miała wpływ na to co wydarzyło się w 2004 roku na Ukrainie. W Pomarańczowej Rewolucji brali udział ludzie, którzy podczas dziesięcioletniego okresu poprzedzającego te wydarzenie mieli szansę na kontakt z polskim społeczeństwem obywatelskim.

Uczeni uważają, że wspieranie powiązań pomiędzy obywatelami oraz z innymi grupami społeczeństwa obywatelskiego ma zasadnicze znaczenie zarówno dla budowania i umacniania społeczeństwa obywatelskiego (McMahon, 2000, s. 253; Henderson, 2002; Richter, 2002; Wilde, 2002, s. 433). Niemniej jednak jedną z istotnych krytyk pomocy, której udzielały państwa i organizacje świata zachodniego było brak tworzenia sieci powiązań pomiędzy grupami społecznymi. Pomoc zagraniczna powodo- 
wała, że te organizacje w krajach odbiorców które otrzymywały środki finansowe na projekty były również głównymi beneficjentami. Spowodowało to dysproporcje pomiędzy tymi organizacjami, które miały łatwy i stały dostęp do środków zagranicznych, a tymi które takiej pomocy nie otrzymywały (,the haves and the have-nots"), ponieważ nie były wystarczająco duże albo nie potrafiły napisać wniosków o pomoc w języku angielskim (Henderson, 2003, s. 10; Narozhna, 2004, s. 248). Brak sieci powiązań może doprowadzić do zaniku nawyków rozwijania współpracy, solidarności i zaufania wśród obywateli, jak również marginalizacji grup społeczeństwa obywatelskiego (Henderson, 2002).

Biorąc pod uwagę tę krytykę, można powiedzieć że współpraca na zasadach partnerstwa, którą stosują polskie organizacje pozarządowe wydaje się być lepszą strategią, ponieważ ułatwia powstawanie wewnętrznych powiązań pomiędzy grupami społeczeństwa obywatelskiego w kraju odbiorcy. Poprzez nakłanianie stałych organizacji partnerskich do poszukiwania partnerów z innych terenów Ukrainy i adresowanie projektów do nowych grup społeczeństwa obywatelskiego z innych lokalizacji, przyczyniają się do ekspansji sektora pozarządowego i powstania nowych więzi, a przez to budowania kapitału społecznego. Takimi projektami są, wspomniane we wcześniejszych fragmentach artykułu, projekty łączące zachodnią i wschodnią Ukrainę.

Projekty organizacji pozarządowych nie tylko wiążą się z korzyściami, jakie wynikają ze współpracy partnerskiej i tworzenia sieci pomiędzy grupami społeczeństwa obywatelskiego, ale również z doświadczeniem, którym sąsiadujący partnerzy mogą podzielić się. To doświadczenie i wiedza wydaje się być bardziej istotne po drugiej stronie granicy, niż w krajach geograficznie odległych, często z powodu historycznej przeszłości i kultury, którą sąsiedzi zazwyczaj dzielą (Carothers, 1999, s. 267). Działacze polskich organizacji pozarządowych uważają, że ich własne doświadczenie reform demokratycznych i wolnorynkowych jest bardziej przydatne w krajach sąsiednich, niż gdzie indziej. $\mathrm{Na}$ przykład, FRDL brała udział w przygotowaniu polskich reform administracyjnych, które są uważane za jedne z najbardziej udanych reform w regionie postkomunistycznym (Regulska, 1998). Mając to doświadczenie i zaangażowanie, FRDL podjęła wysiłki, aby przekazać swoje doświadczenie do krajów, w których reforma samorządowa jest przedmiotem dyskusji lub jest $\mathrm{w}$ interesie publicznym. Wkład FRDL oraz Instytutu Spraw Publicznych na rzecz rozwoju samorządności lokalnej $\mathrm{w}$ regionie postkomunistycznym polegał na przeprowadzaniu szkoleń 
organizowanych dla pracowników sektora publicznego państw-beneficjentów i partii politycznych, jak również tłumaczeń i publikowania polskiej ustawy o reformie administracyjnej w kilku językach regionu postsowieckiego, w tym nawet na język białoruski i azerski. Podobnie, ponieważ polskie NGO były aktywne w przygotowaniu członkostwa Polski w Unii Europejskiej oraz rozpowszechnianiu informacji na temat UE, dziś dzielą się swoimi doświadczeniami z ukraińskimi partnerami, jak przedstawiono wcześniej w artykule.

Wreszcie, we wspieraniu demokracji badacze uznają, że budowanie zrównoważonego społeczeństwa obywatelskiego wymaga ciągłości w finansowaniu i utrzymywaniu długoterminowej współpracy (Siegel, Yancey, 1992; Ottaway, Chung, 1999; Quigley, 2000; Henderson, 2003, s. 153; Jarábik, 2006, s. 86). Według Tudoroiu (Tudoroiu, 2007, s. 340) krótkoterminowe zagraniczne finansowanie może pomóc w rozwoju organizacji pozarządowych, ale nie wystarczy na tyle, aby zapewnić rozpowszechnianie na szeroką skalę wartości demokratycznych wśród społeczności i szybki rozwój społeczeństwa obywatelskiego. Jedną z głównych korzyści wynikających z partnerstwa organizacji pozarządowych ze społeczeństwem obywatelskim jest długoletni i trwały charakter współpracy, który może w większym stopniu przyczynić się do przenikania i wywołania zmiany poglądów i wzorców zachowań osób zaangażowanych we współpracę.

Relacje polskich organizacji pozarządowych z ukraińskimi organizacjami pozarządowymi lub grupami społeczeństwa obywatelskiego na Białorusi, które nieprzerwanie trwają od wielu lat mogą przyczynić się do rozwoju społeczeństwa obywatelskiego i przynieść zamierzone efekty. W wywiadach, przedstawiciele polskich organizacji pozarządowych zapytani o rezultaty ich działalności wskazywali mierzalny wpływ projektów, tj. wskazywali zmiany w danej szkole, wsi lub mieście, które powstały w wyniku ich współpracy z organizacjami lokalnymi, takie jak utworzenie rady dla rodziców w szkole, zespół obsługi klienta w ratuszu, szkolne kluby europejskie itp. Niemniej jednak są wyniki, które są trudno mierzalne, ale na które trzeba spojrzeć z perspektywy dziesięciu lat, zwłaszcza jeśli dotyczy to takich projektów jak stypendia, staże, szkolenia, które wiążą się ze zmianą opinii, postaw i aktywizacją. Naukowcy sugeruja, że wyniki projektów demokratyzacyjnych można również mierzyć nie tylko poprzez poszukiwanie wpływu na instytucje lub w społeczeństwie jako całości, ale także poprzez poszukiwanie zmian w życiu ludzi, czyli beneficjentów tych projektów (Quigley, 1997; Richter, 2002, s. 56). 
Działacze polskich organizacji pozarządowych podają liczne przykłady zmian w postawach i aktywizacji białoruskich czy ukraińskich partnerów oraz uczestników projektów, które można przypisać wpływowi działań organizacji. Za przykład podają ukraińskich działaczy społeczeństwa obywatelskiego, którzy uczestniczyli w pomarańczowej rewolucji, czy dziennikarzy, którzy zaczęli pisać artykuły o tematyce lokalnej lub byłych uczestników projektu, którzy podjęli wysiłki, aby dokonać pewnych zmian w ich własnej społeczności.

Tabela 2

\section{Potencjał polskiej pomocy demokratyzacyjnej w dyfuzji demokratycznych idei i postaw}

\begin{tabular}{||l|l||}
\hline \multicolumn{1}{|c|}{$\begin{array}{c}\text { Negatywne strony wspierania } \\
\text { demokracji }\end{array}$} & \multicolumn{1}{|c||}{$\begin{array}{c}\text { Pozytywne strony wspierania } \\
\text { demokracji przez polskie organizacje } \\
\text { pozarządowe }\end{array}$} \\
\hline Bezosobowe relacje donor-odbiorca. & Partnerskie relacje w realizacji projektów. \\
\hline $\begin{array}{l}\text { Wiedza i narzędzia w rękach donorów bądź } \\
\text { organizacji działających na zlecenie. }\end{array}$ & Tworzenie ,własności lokalnej”. \\
\hline $\begin{array}{l}\text { Podejście szablonowe bez uwzględnienia } \\
\text { specyfiki kraju odbiorcy. }\end{array}$ & $\begin{array}{l}\text { Uwzględnienie tła historycznego, politycz- } \\
\text { nego, społecznego i kulturowego. }\end{array}$ \\
\hline $\begin{array}{l}\text { Uniwersalne podejście do faz rozwoju de- } \\
\text { mokracji. }\end{array}$ & $\begin{array}{l}\text { Uwzględnienie kontekstu krajowego i lo- } \\
\text { kalnego w procesie demokracji. }\end{array}$ \\
\hline $\begin{array}{l}\text { Brak wzorców do naśladowania; nieade- } \\
\text { kwatność doświadczenia kraju donora. }\end{array}$ & $\begin{array}{l}\text { Przydatność doświadczenia reform demo- } \\
\text { kratycznych i wolnorynkowych. }\end{array}$ \\
\hline Wspieranie wyłącznie NGO. & $\begin{array}{l}\text { Wsparcie dla różnych grup społecznych, } \\
\text { nie tylko dla organizacji pozarządowych. }\end{array}$ \\
\hline Dzielenie społeczeństwa obywatelskiego. & $\begin{array}{l}\text { Tworzenie sieci powiązań pomiędzy grupa- } \\
\text { mi społecznymi. }\end{array}$ \\
\hline Myślenie projektowe. & Długoletni i trwały charakter współpracy. \\
\hline Krótkotrwałe finansowanie. & Ciagłość finansowania projektów. \\
\hline \hline
\end{tabular}

Źródło: Opracowanie własne na podstawie krytyki modelów wspierania demokracji w literaturze przedmiotu i własnej analizie działalności polskich organizacji pozarządowych na Białorusi i Ukrainie.

\section{Podsumowanie}

Artykuł pokazuje, że projekty polskich organizacji pozarządowych na Białorusi i Ukrainie oparte są na zasadzie partnerstwa i trwałości współpracy, dlatego poprzez powiązania i ścisłą współpracę społeczeństwo obywatelskie ma większe szanse przetrwania. Przeprowadzone badania pokazują przede wszystkim ważną rolę organizacji pozarządowych 
w promowaniu demokracji, a w szczególności ich zdolność dotarcia do społeczeństwa obywatelskiego w krajach partnerskich. Poprzez lepsze zrozumienie obecnej sytuacji partnerskich organizacji pozarządowych jako organizatorów i młodych ludzi jako uczestników, projekty te zwiększają swoją skuteczność.

$\mathrm{Z}$ analizy przeprowadzonych wywiadów oraz zebranej dokumentacji wynika, że młode kraje demokratyczne aktywnie dzielą się swoim doświadczeniem transformacji systemowej, a współpraca uwzględnia tło historyczne, polityczne, społeczne i kulturowe krajów, które są beneficjentami wsparcia. Współpraca pomiędzy polskim społeczeństwem demokratycznym a prodemokratycznymi grupami na Białorusi może być najbardziej skuteczną formą wspierania demokracji w tym kraju. Wynika to z tego, że takie powiązania pomiędzy społecznościami sprzyjają wprowadzaniu na Białorusi nowych rozwiązań, które bez tej współpracy nigdy by nie powstały. Polskie organizacje pozarządowe uznają, że powodzenie wysiłków związanych ze wspieraniem społeczeństwa obywatelskiego w innych państwach postkomunistycznych jest możliwe tylko we współpracy z podmiotami krajowymi w kraju partnerskim.

Ponadto, przeprowadzone badania pokazuja, że polskie organizacje pozarządowe, które jeszcze niedawno były odbiorcami pomocy rozwojowej, w oparciu o własne doświadczenia mają szansę uniknąć błędów popełnianych przez zachodnich donatorów. Organizacje pozarządowe wydają się lepiej zdawać sobie sprawę z wyzwań, jakie niesie za sobą tego typu współpraca. Rezygnując z „narzucania demokracji” i eksportu ,gotowych rozwiązań” dla krajów na różnym etapie procesu demokratycznego, na rzecz dzielenia się własnymi doświadczeniami i asystowania $\mathrm{w}$ implementacji projektów, ujawniły duży potencjał współpracy partnerskiej społeczeństwa obywatelskiego w dyfuzji demokratycznych idei i postaw.

Podsumowując, projekty organizacji pozarządowych oparte na zasadzie partnerstwa, mają szanse być skuteczne z następujących względów: 1) dostosowują działania do sytuacji politycznej, kontekstu i sytuacji partnera; 2) mają szacunek dla specyfiki kulturowej państw, dzięki czemu wdrażane zmiany bardziej odpowiadają na określone potrzeby; 2) biorą pod uwagę współpracę nie tylko z NGO, ale z różnymi grupami społecznymi; 3) mają na celu długoterminową współpracę. Bliskość geograficzna jest kolejnym ważnym czynnikiem, którego nie można pominąć w analizie projektów polskich organizacji pozarządowych, gdyż ułatwia on dyfuzję norm, postaw i wartości demokratycznych. 


\section{Bibliografia}

AFP (Agence France Presse) (2007), Thousands Rally in Kiev against President, April 2.

Aksartova S. (2005), NGO Diffusion in the former Soviet Union and its Effects, w: Civil. Society from Abroad: U.S. Donors in the Former Soviet Union, $\mathrm{PhD}$ Dissertation, Department of Sociology, Princeton University.

Azpuru D. i in. (2008), Trends in Democracy Assistance: What Has the United States Been Doing?, „Journal of Democracy”, nr 19 (2), ss. 150-159.

Bernard A., Helmich H., Lehning P. B. (1998), Civil Society and International Development, North-South Centre of the Council of Europe and Development Centre Studies of the Organization for Economic Co-operation and Development, Paris.

Bernhard M. (1993), Civil Society and Democratic Transition in East Central Europe, „Political Science Quarterly”, nr 108 (2), ss. 307-326.

Bunce V. J., Wolchik S. L. (2006), International Diffusion and Postcommunist Electoral Revolutions, „Communist and Post-Communist Studies”, nr 39 (3), Ss. 283-304.

Burnell P. (1996), Politics and the Effectiveness of Foreign Aid, „European Economic Review", nr 40, ss. 289-329.

Burnell P. (2000), Democracy Assistance: International Co-operation for Democratization, Frank Cass Co Ltd., London-Portland.

Carothers T. (1999), Aiding Democracy Abroad: The Learning Curve, Carnegie Endowment for International Peace, Washington DC.

Carothers T. (2004), Critical Mission: Essays on Democracy Promotion, Carnegie Endowment for International Peace, Washington DC.

Checkel J. T. (2005), International Institutions and Socialization in Europe: Introduction and Framework, „International Organization”, nr 59.

Chernov V. (2008), Third Sector in Belarus, „Nashe Mneniye Internet Journal”, February 18, http://www.nmnby.org/pub/0802/18m.html.

Diamond L., Plattner M. F. (2001), The Global Divergence of Democracies, The Johns Hopkins University Press, Baltimore-London.

Diamond L. (1994), Rethinking Civil Society: Toward Democratic Consolidation, „Journal of Democracy”, nr 5 (3), ss. 4-17.

Diamond L. (1996), Toward Democratic Consolidation, w: The Global Resurgence of Democracy, red. L. Diamond, M. F. Plattner, The Johns Hopkins University Press, Baltimore.

Drążkiewicz-Grodzicka E. (2013), From a recipient to Donor: The Case of Polish Developmental Cooperation, „Human Organization”, nr 72 (1), ss. 65-75.

Ekiert G., Kubik J. (1999), Rebellious Civil Society: Popular Protest and Democratic Consolidation in Poland, 1989-1993, University of Michigan Press, Ann Arbor. 
Fundacja Stefana Batorego/Grupa Zagranica (2002), Działania polskich organizacji pozarzqdowych adresowane do Białorusi, http://www.klon.org.pl/files/go2east.ngo.pl/public/dzialania_polskich_organizacji_pozarzadowych_adresowane_do_Bialorusi.pdf, 15.05.2016.

Geremek B. (1996), Civil Society Then and Now, w: The Global Resurgence of Democracy, red. L. Diamond, M. F. Plattner, The Johns Hopkins University Press, Baltimore.

Grugel J. (1999), Democracy Without Borders: Transnationalization and Conditionality in New Democracies, Routledge, London.

Grupa Zagranica (2012), Demokracja i rozwój w perspektywie polskich organizacji pozarzadowych.

Hadenius A., Uggla F. (1998), Shaping North-South Centre of the Council of Europe and Development Civil Society, w: Civil Society and International Development, red. A. Bernard, H. Helmich, P. B. Lehning, North-South Centre of the Council of Europe and Development Centre of the Organization for Economic Co-operation and Development, Paris.

Henderson S. H. (2002), Selling Civil Society: Western Aid and the Nongovernmental Organization Sector in Russia, „Comparative Political Studies”, March, nr 35, ss. 139-167.

Henderson S. (2000), Importing Civil Society: Foreign Aid and the Women's Movement in Russia, „Demokratizatsiya”, nr 8 (1), ss. 65-82.

Henderson S. (2003), Building Democracy in Contemporary Russia: Western Support for Grassroots Organizations, Cornell University Press, Ithaca, NY.

Ishkanian A. (2008), Democracy Building and Civil society in Post-Soviet Armenia, Routledge, London.

Jacoby W. (2006), Inspiration, Coalition, and Substitution: External Influences on Postcommunist Transformations, „World Politics”, nr 58 (4), ss. 623-651.

Jarábik B. (2006), International Democracy Assistance to Belarus: An Effective Tool?, w: Prospects for Democracy in Belarus, red. J. Forbrig, D. R. Marples, P. Demeš, The German Marshall Fund of the United States and Heinrich Boll Stiftung, Washington DC.

Keck M. E., Sikkink K. (1998), Activists Beyond Borders: Advocacy Networks in International Politics, Cornell University Press, Ithaca-London.

Kieżun W. (2011), Patologia transformacji, Wydawnictwo Poltext, Warszawa.

Kucharczyk J., Lowitt J. (2008), Democracy's New Champions: European Democracy Assistance after EU Enlargement, PASOS, Praga.

Kugiel P. (2011), V4 Development Cooperation: Challenges and Prospects for Common Actions, „PISM Bulletin”, nr 102 (319).

Kuzio T. (2007), Political Tourism and Managed Civil Society in Ukraine, „Eurasia Daily Monitor", May 22, nr 4 (100), http://www.jamestown.org/single/?no_ cache $=1 \&$ tx_ttnews $\% 5$ Btt_news $\% 5 \mathrm{D}=32759$.

Kuzio T. (2006), Everyday Ukrainians and the Orange Revolution, w: Revolution in Orange: The Origins of Ukraine's Democratic Breakthrough, red. 
A. Åslund, M. McFaul, Carnegie Endowment for International Peace, Washington DC.

Lancaster C. (2007), Foreign Aid: Diplomacy, Development, Domestic Politics, University of Chicago Press, Chicago.

Lehning P. B. (1998), Towards a Multi-cultural Civil Society: The Role of Social Capital and Democratic Citizenship, w: Civil Society and International Development, red. A. Bernard, H. Helmich, P. B. Lehning, North-South Centre of the Council of Europe and Development Centre of the Organization for Economic Co-operation and Development, Paris.

Lenzi M. (2002), Lost civilization: the thorough repression of civil society in Belarus, „Demokratizatsiya”, vol. 10, nr 3, ss. 401-424.

Lightfoot S., Szent-Ivantyi B. (2014), Reluctant Donors? The Europeanization of International Development Policies in the New Member States, „Journal of Common Market Studies", vol. 52, nr 6, ss. 1-16.

Linz J. J., Stepan A. (1996), Problems of Democratic Transition and Consolidation: Southern Europe, South America, and Post-Communist Europe, John Hopkins University Press, Baltimore.

McFaul M. (2005), Democracy Promotion as a World Value, „Washington Quarterly”, nr 28 (1), ss. 147-163.

McMahon P. (2000), Building Civil Societies in East Central Europe: The Effect of American Non-governmental Organizations on Women's Groups, w: Democracy Assistance: International Co-operation for Democratization, red. P. Burnell, Frank Cass Co. Ltd., London-Portland.

McMahon P. (2002), International Actors and Women's NGOs in Poland and Hungary, w: The Power and Limits of NGOs: A Critical Look at Building Democracy in Eastern Europe and Eurasia, red. S. E. Mendelson, J. K. Glenn, Columbia University Press, New York.

McMahon P. (2004), Building Civil Societies in East Central Europe: The Effect of American Non-governmental Organizations on Women's Groups, w: Civil Society in Democratization, red. P. Burnell, P. Calvert, Routledge, New York.

Mendelson S. E. (2001), Democracy Assistance and Political Transition in Russia, „International Security”, nr 25 (4), ss. 68-106.

Mendelson S. E., Glenn J. K. (2002), The Power and Limits of NGOs: A Critical Look at Building Democracy in Eastern Europe and Eurasia, Columbia University Press, New York.

Mitilin D. (1998), The NGOs Sector and its Role in Strengthening Civil Society and Securing Good Governance, w: Civil Society and International Development, red. A. Bernard, H. Helmich, P. B. Lehning, North-South Centre of the Council of Europe and Development Centre of the Organization for Economic Cooperation and Development, Paris.

MSZ (2008), Ministerstwo Spraw Zagranicznych Departament Współpracy Rozwojowej. Raport Roczny 2008, https://www.polskapomoc.gov.pl/.../RAPORT_ ROCZNY_MSZ_2008_PL_maly.pdf. 
MZS (2006), Ministerstwo Spraw Zagranicznych: Wieloletni program wspótpracy rozwojowej na lata 2016-2020.

Narozhna T. (2004), Foreign Aid for a Post-Euphoric Eastern Europe: the Limitations of Western Assistance in Developing Civil Society, „Journal of International Relations and Development", nr 7, ss. 243-266.

Ottaway M., Chung T. (1999), Debating Democracy Assistance: Toward a New Paradigm, ,Journal of Democracy”, nr 10 (4), ss. 9-113.

Ottaway M., Carothers T. (2000), Funding Virtue: Civil Society Aid and Democracy Promotion, Carnegie Endowment for International Peace, Washington DC.

Petrova T. (2014), From Solidarity to Geopolitics: Support for Democracy Among Postcommunist States, Cambridge University Press, Cambridge.

Pospieszna P. (2010a), When Recipients Become Donors: Polish Democracy Assistance in Belarus and Ukraine, „Problems of Post-Communism”, nr 57 (4), ss. $3-15$.

Pospieszna P. (2010b), New EU Member States Taking the Lead in Democracy Aid: The Polish Case, w: The European Union's Neighborhood Challenge. Transborder cooperation, migration and Europeanization, red. K. Bachmann, E. Stadtmuller, Wrocław University Press, Wrocław.

Pospieszna P. (2014), Democracy Assistance from the Third Wave: Polish Engagement in Belarus and Ukraine, The University of Pittsburgh Press.

Quigley K. F. F. (1997), For Democracy's Sake: Foundations and Democracy Assistance in Central Europe, Woodrow Wilson Center Special Studies, Washington DC.

Quigley K. F. F. (2000), Lofty Goals, Modest Results: Assisting Civil Society, w: Funding Virtue: Civil Society and Democracy Promotion, red. M. Ottaway, T. Carothers, Carnegie Endowment for International Peace, Washington DC.

Rada Unii Europejskie (2005), External Relations Council: Accelerating progress Towards Achieving the Millenium development Goals, http:/www.unmillenniumproject.org/documents/EUExternalRelations24May.pdf, 16.05.2016.

Raik K. (2006), Making Civil Society Support Central to EU Democracy Assistance, w: Prospects for Democracy in Belarus, red. J. Forbrig, D. R. Marples, P. Demeš, The German Marshall Fund of the United States and Heinrich Boll Stiftung, Washington DC.

Regulska J. (1998), The rise and fall of public administration reform in Poland: why bureaucracy does not want to be reformed, w: Local Development and Public Administration in Transition, red. M. Barlow, I. Lengyel, R. Welch, J. Attila, University: Szeged, Hungary.

Richter J. (2002), Promoting Civil Society?: Democracy Assistance and Russian Women's Organizations, „Problems of Post-Communism”, nr 48 (1), ss. 30-41.

Rose-Ackerman S. (2007), From Elections to Democracy: Building Accountable Government in Hungary and Poland, Cambridge University Press. 
Sannikov A., Kuley I. (2006), Civil Society and the Struggle for Freedom, w: Prospects for Democracy in Belarus, red. J. Forbrig, D. R. Marples, P. Demeš, The German Marshall Fund of the United States and Heinrich Boll Stiftung, Washington DC.

Schifter M. (2000), Latin American Democratization: The Civil Society Puzzle, w: Funding Virtue: Civil Society and Democracy Promotion, red. M. Ottaway, T. Carothers, Carnegie Endowment for International Peace, Washington DC.

Sedogo P. F. (1998), Civil Society in Sub-Saharan Africa: How Can Western Countries Help Civil Society in Africa?, w: Civil Society and International Development, red. A. Bernard, H. Helmich, P. B. Lehning, North-South Centre of the Council of Europe and Development Centre of the Organization for Economic Co-operation and Development, Paris.

Schimmelfennig F., Engert S., Knobel H. (2006), International Socialization in Europe: European Organizations, Political Con-ditionality and Democratic Change, Palgrave Macmillan, New York.

Siegel D., Yancey J. (1995), The Rebirth of Civil Society: The Development of the Nonprofit Sector in East Central Europe and the Role of Western Assistance, The Rockefeller Fund, New York.

Smith J., Chatfield C., Pagnucco R. (1997), Transnational Social Movements and Global Politics: Solidarity Beyond the State, Syracuse University Press, New York.

Sundstrom L. M. (2006), Funding Civil Society: Foreign Assistance and NGO Development in Russia, Stanford University Press.

Tarrow S. (1998), Power in Movement: Social Movements and Contentious Politics, Cambridge University Press.

Tarrow S. (2005), The New Transnational Activism, Cambridge University Press, Cambridge.

Tudoroiu T. (2007), Rose, Orange, and Tulip: The Failed Post-Soviet Revolutions, „Communist and Post-Communist Studies”, nr 40 (3), ss. 315-342.

USAID Mission to Poland Europe and Eurasia. USAID and the Polish Decade 19891999, http://www.usaid.gov/pl/close-ou.htm\#SHOWING\%20SUPPORT\%20 IN\%20EVERY\%20WAY\%20POSSIBLE.

Usau P. (2007), Pro-Government Associations in Belarus. In Hopes, Illusions, Perspectives: Belarusian Society 2007, East European Democratic Center, Warsaw-Minsk.

Wedel J. R. (2001), Collision and Collusion: The Strange Case of Western Aid to Eastern Europe, Palgrave for St. Martin's Griffin, New York, NY.

Wilde C. (2002), The Challenge of Using NGOs as a Strategy for Engagement, w: Independent Belarus: Domestic Determinants Regional Dynamics, and Implications for the West, red. M. M. Balmaceda, J. I. Clem, L. L. Tarlow, Ukrainian Research Institute of Harvard University, The Davis Center for Russian and Eurasian Studies, Cambridge. 


\title{
Democratization aid offered by Polish non-governmental organizations to Belarus and Ukraine: premises and different forms of support
}

\begin{abstract}
Summary
Supporting democracy or, in other words, a special kind of foreign aid aiming to promote democratic ideas and attitudes, has been the domain of western democracies. Therefore, the studies on aiding democracy have typically focused on the programs of international organizations, governmental and non-governmental organizations and foundations from the United States and Western Europe. Recently, the circle of benefactors widened to include also the young democracies from Central and Eastern Europe - Poland, the Czech Republic, Slovakia and Hungary - the former recipients of a similar support. The case study of Polish involvement in Ukraine and Belarus allows the author of this paper to analyze the activities of Polish NGOs aiming to support democracy in partner countries from 1990 to 2015. The objective is to examine the reasons for Polish NGOs involvement in supporting democracy, the methods applied to promote democratic ideas and attitudes and the nature of collaboration with civil societies of partner countries.
\end{abstract}

Key words: democracy assistance, CEE, Belarus, Ukraine, NGOs 